To cite: C Stevens 'Reviving the right to development within the multilateral trade framework affecting (African) countries to actualise Agenda 2063' (2019) 19 African Human Rights Law Journal 470-493

http://dx.doi.org/10.17159/1996-2096/2019/v19n1a22

\title{
Reviving the right to development within the multilateral trade framework affecting (African) countries to actualise Agenda 2063
}

\author{
Clydenia Stevens* \\ PhD Student, University of KwaZulu-Natal, Durban, South Africa \\ https://orcid.org/0000-0003-0712-501X
}

\section{Summary}

The African Union through Agenda 2063 aspires to build 'a prosperous Africa based on inclusive growth and sustainable development' and to ensure that Africa becomes 'a strong, united, resilient and influential global player and partner'. Similarly, the World Trade Organization aims to ensure that member states through the multilateral trade system can 'raise standards of living', 'ensure full employment' and 'sustainable development'. Both institutions seem to be aware that African countries are underdeveloped and require assistance to address the cohort of political and socio-economic challenges, and the implementation of particular practices and policies in order for the continent to be a force in the multilateral trade arena. Indeed, the unequal economic relations between states in the multilateral trading system add to the afflictions of African countries. The position of the right to development as a recognised human right has become an acceptable and settled notion. This article aims to provide and identify possible ways whereby the international community and African countries can rescue the right to development from the 'conceptual mudslinging and political quicks, in which it has been mired all these years' in the trade discipline. Indeed, trade goes hand-in-hand with development but 'is not the sole determinant for

\footnotetext{
LLB LLM (Western Cape); stevens@ukzn.ac.za. This article was prepared while the author was a doctoral candidate at the School of Law, University of KwaZuluNatal, and contains some matters raised in her doctoral thesis. I am indebted to Mr Christopher Gevers and Prof Shannon Bosch of the University of KwaZuluNatal for carefully providing constructive criticism on earlier drafts of the article, which shaped the work. I would also like to thank Dr Carol Ngang for his assistance and the reviewers for their insightful comments. However, all shortcomings and views expressed herein remain those of the author.
} 
development', and there is a need to revive the right to development in the multilateral trade framework as trade is a valuable tool for actualising Africa's Agenda 2063 and the development of African countries. The article provides a succinct overview of the right to development and particular multilateral trade practices, programmes and policies and puts forward an argument of how Africa's attempt to address its economic, political and social ills can be addressed through Agenda 2063.

Key words: right to development; multilateral trade; World Trade Organization; Agenda 2063

\section{Introduction}

The African Union (AU) through Agenda 2063 aspires to build 'a prosperous Africa based on inclusive growth and sustainable development' and to ensure that Africa becomes 'a strong, united, resilient and influential global player and partner'. ${ }^{1}$ Furthermore, it aspires to ensure that 'Africa's agriculture will be modern and productive, using science, technology, innovation and indigenous knowledge'.2 Agenda 2063 may be considered a strategy for corroborating the initiatives of the $A U$ and the United Nations (UN) and can be construed as a 'revived plan' for addressing the economic, political and social difficulties facing Africa. In its implementation plan (2014-2023) to integrate Africa, Agenda 2063 aims to ensure the 'free movement of goods, services and capital and to increase the volume of intra-African trade especially in agricultural value added products threefold, by 2023'. ${ }^{3}$ The Guiding Principles, which include subsidiarity, accountability and transparency, inclusiveness and integration, are key to the overall implementation of the Agenda.

History suggests that, for various reasons, African countries are underdeveloped, a situation which thwarts their participation in the multilateral trade arena. While the unbalanced economic relations between states in the multilateral trading system add to the challenges these countries face, it is not the sole attributor. ${ }^{4}$ The question is whether these challenges can be overturned by means of internal African trade cooperation that is spearheaded through Agenda 2063 and related plans. As such, the impact of Agenda 2063 should be considered in respect of the position of African countries

1 African Union Commission 'Agenda 2063: The Africa we want' Aspirations 1 and 7 (2015) http://www.un.org/en/africa/osaa/pdf/au/agenda2063-first10yearimple mentation.pdf (accessed 25 May 2018).

2 As above.

3 African Union Commission 'Agenda 2063: The Africa we want: A shared strategic framework for inclusive growth and sustainable development: First ten-year implementation plan 2014-2023' (2015) 21-23 http://www.un.org/en/africa/ osaa/pdf/au/agenda2063-first10yearimplementation.pdf (accessed 25 May 2018).

4 E Kessie \& Y Apea 'The participation of African countries in the multilateral trading system' (2004) 12 African Yearbook of International Law 9-10. 
and the operation of the current practices, programmes and policies of the Word Trade Organisation (WTO) and other agencies.

Limited market access, exorbitant non-tariff measures and other barriers are some of the leading concerns for Southern African Development Community (SADC) and Economic Community of West African States (ECOWAS) members. ${ }^{5}$ Frequently, the underdevelopment of African countries generally is placed at the door of perpetual reliance on mainly trade policies, programmes and binding international conventions that are not specifically suited to their economic circumstances. Despite the allure of the promised membership to this multilateral body governing international trade, African countries are still left out in the cold. To remedy the situation the continent, through Agenda 2063, seeks to develop the 'right strategies to finance its own development and further reduce aid dependency'. ${ }^{6}$ Currently, many African developing and least developed countries are heavily reliant on official development assistance and other forms of development assistance to enable their multilateral, regional and bilateral economic participation. ${ }^{7}$ Agenda 2063 is dissimilar to the array of 'one-size-fit-all' programmes proffered by the WTO and other agencies, and is more focused on an African plan for actualising the right to development.

If Agenda 2063 aims to streamline Africa's position in the international economic order, the realisation and implementation of the right to development must be an integral component of this 'master plan'. In order for this Agenda to make a difference it would need to identify and address the prevailing impediments in the multilateral trading system that affect the objectives of the acclaimed Agenda and thus the prospect of future development. Development unquestionably is the 'catch phrase' of Agenda 2063, similar to the disillusioned Doha Development Agenda (DDA). However, there appears to be a difference as the Agenda (at least on paper) is strategic in relation to the methods and modes of implementation to achieve the necessary development in Africa. An ideal development framework would encompass coherent and inclusive political, economic and social governance, which requires individual and collective cooperation.

Notwithstanding the vehement call for the realisation and implementation of the right to development after the

5 United Nations Conference on Trade and Development (UNCTAD) 'Regional integration and non-tariff measures in the Economic Community of West African States (ECOWAS)' (2018); UNCTAD/DITC/TAB/2018/1 https://unctad.org/en/ PublicationsLibrary/ditctab2018d1_en.pdf; United nations Conference on Trade and Development (UNCTAD) 'Non-tariff measures and regional integration in the Southern African Development Community' (2014) (UNCTAD/DITC/TAB/2014/5) https://unctad.org/en/PublicationsLibrary/ditctab2014d5_en.pdf (accessed 5 March 2019).

6 African Union Commission (n 3).

7 MA Tadeg 'Reflections on the right to development: Challenges and prospects' (2010) 10 African Human Rights Law Journal 339. 
commemoration of the 25th anniversary of the Declaration on the Right to Development (RTD Declaration) ${ }^{8}$ in 2011, and the ample recognition of the link between human rights and development, the place of the right to development in multilateral trade remains unclear. In particular, the normative and legal framework of multilateral trade reflects the perplexing nature of these interlinked areas. A relevant example here is the above-mentioned Doha Round, or the so-called 'Development Round', which has placed development at its centre, although the focus has since then faded. Given the challenges faced by African countries in the multilateral trading system, a discussion on the implementation of the right to development is crucial.

Owing to the broad nature of the right to development and the common practice of couching it in the human rights framework, it often is 'narrowly understood when analysed from an economic growth perspective'. 9 It is submitted that the interpretation of the right to development does not have to be through a singular approach, but can encompass different lenses (human rights, economic, social, political, legal and cultural) as the nature of the right to development lends itself to such flexibility. Thus, by following such an all-encompassing approach, the interpretation and implementation of the right to development will be key to (i) addressing inequity in multilateral trade; (ii) achieving Agenda 2063; and (iii) strengthening regional economic integration efforts.

The structure of the article is as follows: Part 2 highlights the salient features of the right to development, as specifically contained in the RTD Declaration and the African Charter on Human and Peoples' Rights (African Charter). ${ }^{10}$ This is followed by an in-depth discussion in part 3 of the WTO's approach to development, where current policies and practices implemented by the institution to 'enable' development are discussed. Part 4 elaborates on the above-mentioned AU Agenda 2063 objectives, with a view to understanding the rationale for this plan and to deliberate on the relevance of current external and internal tools and programmes to enable development in African countries. The conclusion and recommendations follow in part 5.

The discussion on the need to situate the right to development within the framework of multilateral trade to actualise the African Agenda for development aims to provide and identify potential ways whereby the international community and African countries can rescue the right to development from the 'conceptual mudslinging

8 Art 3(3) Declaration on the Right to Development GA Res A/RES/41/128 1986 (United Nations 1986).

9 C Ngang 'Towards a right-to-development governance in Africa' (2018) 17 Journal of Human Rights 108.

10 African Charter on Human and Peoples' Rights adopted in Nairobi on 27 June 1981 OAU Doc CAB/LEG/67/3 rev 5, 21 ILM 58. 
and political quicks in which it has been mired all these years ${ }^{11}$ in the trade discipline.

\section{Right to development}

\section{Meaning of the right to development}

Generally identified as a 'third generation solidarity right', the right to development is recognised at the international, regional and national levels. ${ }^{12}$ Described as a means to 'mark the development of human rights through time', 13 the emergence of solidarity rights in the twentieth century - similar to civil-political and socio-economic rights - has to be understood within the historical context and processes. ${ }^{14}$ Solidarity rights did not replace civil-political or socio-economic rights, but owing to the evolution in human rights they are essential for the promotion and realisation of these rights. ${ }^{15}$ In fact, by so doing development of the individual and community is assured. Unfortunately, solidarity rights also have to face the same challenges (if not more) encountered by socio-economic rights. In respect of a lack of resources, despite the ample arguments dismissing the myth of their separateness, the different treatment of the three divisions of human rights continues.

Sengupta sheds some light on the rationale for the continuation of this different treatment. According to the author, particularly the right to development usually is merely observed as an 'aspirational right, which can only be aimed at but not realised'. ${ }^{16}$ Stevens and Ntlama ${ }^{13}$ argue that the right to development definitely is an umbrella right and, thus, a failure to meet the cluster of human rights in turn amounts to a failure to meet the right to development. Similarly, Schrijver elaborates that the right to development can be viewed as a 'cluster right, bringing together civil and political rights on the one

11 Navi Pillay, former UN High Commissioner for Human Rights on the occasion of the commemoration of the 25th anniversary of the Declaration on the Right to Development in 2011, http://www.up.ac.za/en/ (accessed 25 March 2018).

12 A Sengupta 'Preface' in SP Marks (ed) Implementing the right to development: The role of international law (2008) 7-8. Shrijver also reiterates that the right to development 'gets its legitimacy' from the Charter of the United Nations (UN), the Universal Declaration of Human Rights, the International Covenant on Civil and Political Rights (ICCPR) and the International Covenant on Economic, Social and Cultural Rights (ICESCR); E Gokce 'Session 2: The right to development: A tool to boost coherence between trade, development and human rights?' taken from N Schrijver Panellists, 15 September 2010 https://www.wto.org/english/ forums_e/public_forum10_e/session02_summ_e.doc (accessed 14 June2018).

13 C Wellman 'Solidarity, the individual and human rights' (2000) 22 Human Rights Quarterly 640.

14 As above.

15 Wellman (n 13) 641.

16 Sengupta (n 12) 8.

17 C Stevens \& N Ntlama 'An overview of South Africa's institutional framework in promoting women's right to development' (2016) 20 Law, Democracy and Development 51. 
hand and economic, social and cultural rights on the other'. ${ }^{18}$ Indeed, if one follows conventional theories, when human rights are protected trade will flow, economies will stabilise and growth will be realised. ${ }^{19}$

Mubangizi argues that due to the interchangeable use of development in different disciplines, its meaning and processes are altered to fit into that specific discipline or even paradigms. ${ }^{20}$ As such, the term often has been used in the following variations: 'human development', 'economic development' and 'sustainable development' 21 However, a dual argument in respect of this also can be contemplated. Defining the term narrowly could result in restraining the application and confining it to a singular box, which would compromise the 'umbrella argument' discussed previously. Meanwhile, if it was defined in a broader context that encompasses all the different variables of politics, economics, human rights and so forth, it could result in a more holistic developmental position.

Despite the elegant wordiness of the concept ${ }^{22}$ and the advances made, Cheru points out that there remains a 'gap in translating the right to development into policy and practice'. ${ }^{23}$ Hansungule also questions the appropriateness of the current definition of the right to development, and the United Nations Conference on Trade and Development (UNCTAD) formula in 'categorising' countries according to their level of development. ${ }^{24}$ Notably, within the respective framework of human rights and multilateral trade there are ample different substantive and procedural approaches, but both share the core objective of development.

In spite of these different approaches, the right to development certainly influences political decisions and economic plans as its very being is centred on the progression of these unpredictable disciplines. Furthermore, in light of the entitlement and duties imparted by article 22 of the African Charter, Agenda 2063 encapsulates these notions and recognises that development cannot materialise if these issues are not dealt with in an appropriate and sustainable order and, thus, calls

\section{Gokce (n 12).}

19 SF Musungu 'Economic integration and human rights in Africa: A comment on conceptual linkages' (2003) 3 African Human Rights Law Journal 94.

20 JC Mubangizi 'A human rights-based approach to development in Africa: Opportunities and challenges' (2014) 39 Journal of Social Sciences 68.

21 As above.

22 Vandenbogaerde writes: 'However, the right to development and its subsequent claims are actually much older and were born out of the era of decolonisation where they found a re-articulation, in the language of rights, of long-standing claims which had been evident both throughout much of the period of colonialism and the years immediately following liberation.' A Vandenbogaerde 'The right to development in international human rights law: A call for its dissolution' (2013) 31 Netherlands Quarterly of Human Rights 189.

23 F Cheru 'Developing countries and the right to development: A retrospective and prospective African view' (2016) 37 Third World Quarterly 1268.

24 M Hansungule 'Keynote address' presented at 2nd International Conference on the Right to Development, Centre for Human Rights, University of Pretoria, South Africa, 15-17 August 2018 (on file with author). 
for 'particular attention to paid to the right to development'. ${ }^{25}$ Indeed, the African Charter recognises the link between civil and political and economic, social and cultural rights and development. As such, the domestication and implementation of the African Charter and other related instruments ${ }^{26}$ are key to the success of Agenda 2063.

Furthermore, articles 1 and 2 of the RTD Declaration extend the meaning of development from the economic framework to the social, cultural and political sphere, thus recognising the so-called 'umbrella effect' of the right to development. Ideally, if the aspirations of Agenda 2063 are to be achieved, scholars should stop regarding the right to development as a separate right. The right should aptly be considered an 'umbrella right', under which all rights function and without which economic development would be unattainable. By expressly acknowledging the right to development as being an 'umbrella right', it would muffle those arguments that question the relevance of the right to development. ${ }^{27}$ These opposing sentiments undeniably are derailing the advances made to the right to development, especially since the debate now is focused on identifying sustainable mechanisms to enable the realisation of this right.

\subsection{Whose right to development?}

M'baye emphasised that 'every person should enjoy in just measure the goods and services produced thanks to the effort of solidarity of the members of the community' ${ }^{28}$ The wording of the RTD Declaration unequivocally reiterates that everyone is 'entitled to participate in, contribute to, and enjoy economic, social, cultural and political development'. 29 By means of the Millennium Declaration, which states that '[w]e are committed to making the right to development a reality for everyone and to freeing the entire human race from want', ${ }^{30}$ Piron adds that the right to development has been

25 Preamble African Charter.

26 Convention on the Elimination of All forms of Discrimination Against Women (CEDAW) and African Women's Protocol; African Union Commission (n 3) 77-78.

27 J Donnelly 'In search of the unicorn: The jurisprudence and politics of the right to development' (1985) California Western International Law Journal 473-477; J Srirang 'A critique of right to development' (2013) 1 Journal of Politics and Governance 17-22.

28 R Ozoemena \& M Hansungule 'Development as a right in Africa: Changing attitude for the realisation of women's substantive citizenship' (2014) 18 Law, Democracy and Development 226 (my emphasis).

29 Article 1(1) states that '[t]he right to development is an inalienable human right by virtue of which every human person and all peoples are entitled to participate in, contribute to, and enjoy economic, social, cultural and political development, in which all human rights and fundamental freedoms can be fully realised'.

30 General Assembly United Nations Millennium Declaration Resolution adopted by the General Assembly A/RES/55/2 18 September 2000 para 11. 
reaffirmed as a universal and inalienable human right. ${ }^{31}$ It intrinsically is both an individual and collective right. As observed from the African Charter, the role of states (acting on the international, regional and national plane) ${ }^{32}$ and the individual (whether acting on his or her own accord or collectively within community structures) is recognised.

Furthermore, since development is a precondition for social life, ${ }^{33}$ the RTD Declaration recognises the human person not only as the 'central subject of [the] development process and that development policy should therefore make the human being the main participant and beneficiary of development ${ }^{\prime},{ }^{34}$ but also identifies states as the duty bearers for the responsibility of development. Hence, the individual not merely is a beneficiary but also a key role player in enforcing the right to development and facilitating the processes in the realisation of development. ${ }^{35}$

The right to development commonly and incorrectly ${ }^{36}$ is referred to as a 'developing country right', mainly due to these nations' former involvement and their insistence on the inclusion of the right in the prevailing human rights dialogue. The right to development, however, certainly is not aimed at developing countries only. Indeed, the right to self-determination ${ }^{37}$ and the subsequent decolonisation of African countries were key factors that encouraged the call for the realisation of development aid programmes. Article 1(2) of the RTD Declaration gives homage to this:

The human right to development also implies the full realization of the right of peoples to self-determination, which includes, subject to the relevant provisions of both International Covenants on Human Rights, the exercise of their inalienable right to full sovereignty over all their natural wealth and resources.

As such, these events and discourses have led to the right to development being regarded as the means to addressing the

31 L Piron 'The right to development: A review of the current state of the debate for the department of international development' (2002) 9 https://www.odi.org/ sites/odi.org.uk/files/odi-assets/publications-opinion-files/2317.pdf (accessed 12 September 2018).

32 SDA Kamga 'Realising the right to development: Some reflections' (2018) 16 History Compass 2-10.

33 Stevens \& Ntlama (n 17) 52.

34 Preamble to the RTD Declaration paras 12 \& 13; RF Oppong 'Trade and human rights: A perspective for agents of trade policy using a rights-based approach to development' (2006) 6 African Human Rights Law Journal 126-127.

35 E Gokce 'Session 2: The right to development: A tool to boost coherence between trade, development and human rights?' Taken from J Hivonnet Panellists, 15 September 2010 https://www.wto.org/english/forums_e/public_forum10_e/ session02_summ_e.doc (accessed 14 June 2018).

36 According to Sengupta, many developed countries also joined the 'sponsorship of the right' as the right to development quite rightly enjoyed by individuals from developing and developed countries; Sengupta (n 12) 7-8.

37 The right to self-determination is proffered as the legal basis for the claim of colonial countries to self-rule and decolonisation; I Dugard International law: A South African perspective (2011) 99. 
challenges faced by the so-called Third World. Sengupta concedes that developing countries in most circles are regarded as the 'principal sponsors $^{38}$ of this right. Reacting to the various arguments, Stevens and Ntlama contextualise the link between developing countries and the right to development, and the role in the economic emancipation of these countries, by explaining: ${ }^{39}$

The emergence of developing countries from the restraint and bondage of colonialism made them search for measures designed to cultivate the right to development in order to gain economic independence and thus the restructuring of their previous economic status quo. This was driven by the eagerness to bridge the gap on economic development in relation to the unevenly balanced distribution of resources between developed and developing countries.

Moreover, these authors dispel the misguided notion that the right to development is new to the international framework, when in fact it actually was born out of the period of decolonisation. Expectedly, then, it was parallel to the recognition of former colonial states and their inhabitants emerging from the shackles of colonial rule to advance the economic, political and social dimensions. In this respect, Vandenbogaerde acknowledges that 'the implementation of the right to development has been slow'. ${ }^{40}$ Furthermore, the author equates the slow pace to the 'highly political nature' of the right. ${ }^{41}$ Nevertheless, in reality development is an all-encompassing process that needs time and proper planning to be realised, knowing the internal and external struggles faced by many (African) countries. ${ }^{42}$ Even though developing countries were the principal proponents of this right, many developed countries joined the movement's sponsorship, and the right is exercised and enjoyed by individuals from both developed and developing countries, similar to other recognised human rights. Thus, the outcomes of the right to development dispel the argument that its sole existence is for developing countries. According to Sengupta, many of the debates on the position of the right to development as a recognised human right have become an acceptable and settled notion. ${ }^{43}$ However, in reality human beings have not always been the 'central object' of development. ${ }^{44}$ Thus, the responsibility of the facilitation, subsequent implementation and ensuring the effectiveness and sustainability of the right to development for all stakeholders concerned is not settled.

38 Sengupta (n 12) 7-8.

39 Stevens \& Ntlama (n 17) 50 (my emphasis); see also Ozoemena \& Hansungule (n 28) 224.

40 Vandenbogaerde (n 22) 189.

41 As above.

42 Oppong (n 34) 127 urges that when dealing with the right to development, one must be careful not to confuse the 'process' and the 'right'.

43 Sengupta (n 12) 7-8.

44 Oppong (n 34) 126. 


\section{Development in the World Trade Organization: 'Economic growth is not an end in itself' 45}

Following the economic devastation caused by the two World Wars and the subsequent depressions, the international community sought to reconstruct the world order. Despite some of the so-called 'birth defects $^{46}$ of the General Agreement on Tariffs and Trade (GATT), ${ }^{47}$ this legal instrument which operated as a de facto organisation ${ }^{48}$ for a long time chartered trade relations between the contracting parties. Furthermore, it was considered favourably by some authors because of the flexibility it offered (commonly referred to as the GATT à la carte) and the minimal intrusiveness in respect of the rights and powers of the contracting parties. ${ }^{49}$ On the other hand, the development of the economies of developing and least developed countries not necessarily was a key focus of the GATT. When this instrument was drafted and negotiated, most developing and least developed countries remained under the control of their colonial occupiers. The GATT thus was unable to muster the continued social, political and economic divide between the north and the south and to coordinate policies and practices that could serve the development needs of these countries.

However, throughout the early part of the GATT negotiations (between 1947 and 1994) some effort was made to consider the challenges faced by developing and least developed countries. As such, having surpassed the complicated negotiations at the Uruguay Round $^{50}$ and 'Battle of Seattle', 51 developing and least developed countries had a renewed interest and bravery forged by their overwhelming numerical advantage, to bring to the fore those issues of concern to them, but which had been neglected in previous trade discussions. This encounter would have to take place at the helm of the newly-formed trade institution. In 1995 the WTO with great fanfare revived the trade relations among the contracting parties of

\footnotetext{
45 http://www.un.org/en/events/righttodevelopment/ (accessed 21 June 2018).

46 JH Jackson The World Trade Organization: Constitution and jurisprudence (1998) 37.

47 GATT 1947: General Agreement on Tariffs and Trade 30 October 1947, 61 Stat Pt 5, 55 UNTS 194.

48 Jackson (n 46) 37.

49 A Saurombe \& HIV Nkabinde 'Reforming the multilateral decision-making mechanism of the WTO: What is the role of emerging economies?' (2013) 16 Potchefstroom Electronic Law Journal 429-436.

50 The Uruguay Round negotiating results were formally signed at Marrakesh, Morocco in 1994, and after being ratified by the required number of nations entered into force on 1 January 1995.

51 In 1999, at the start of Third WTO Ministerial Conference, thousands of protestors met to show their displeasure at the WTO whom they considered in 'developing its rules and procedures for promoting free trade, had not given adequate, or any, consideration to labour rights, environmental problems, or human rights'; C Summers 'The battle in Seattle: Free trade, labour rights, and societal values' (2001) 22 University of Pennsylvania Journal of International Economic Law 61-62.
} 
GATT $1994^{52}$ and other nations. This institution would replace the status quo under the previous regime, by having a developmentinclusive focus. Furthermore, the WTO promised to provide a 'common institutional framework for the conduct of trade relations among its members in matters relating to the agreements and associated legal instruments'. ${ }^{53}$ There undoubtedly was apprehension about how the new institution would function and address the specific needs of developing and least developed countries. The reason for the lack of 'interest' in development is because development often is referred to as a mere 'non-trade concern'.54 However, development is an integral part of the objectives of the WTO and the fostering of a fair international trade system that is important for actualising development.

The WTO ambitiously seeks to administer the trade agreements between its members; to serve as a forum for trade negotiations and settle trade disputes; to review or monitor members' trade policies by the Trade Policy Review Mechanism (TPRM); to cooperate with relevant international organisations; and to provide technical assistance to developing and least developed members. ${ }^{55}$ This mandate is given impetus by the institution's principles, which include: 56

- non-discrimination (most-favoured nation and national treatment

principle): ${ }^{5}$

- $\quad$ free trade gradually through negotiation;

- $\quad$ predictability, through binding agreements and transparency;

- $\quad$ promoting fair competition; and (of particular relevance)

- $\quad$ encouraging development.

These principles form the backbone of the WTO and its stated purpose to liberalise and erode obstacles to multilateral trade (however it also impacts regional and bilateral trade). Furthermore, the principles are given effect by practices, policies and programmes that ensure the operation of the WTO through the various agreements, covering goods, services and intellectual property. ${ }^{58}$ Lastly, but of great importance, is a consideration of the extent to which the current WTO framework enables the realisation of the right to development.

52 GATT 1994: General Agreement on Tariffs and Trade 1994, 15 April 1994, Marrakesh Agreement Establishing the World Trade Organization, Annex 1A, 1867 UNTS 187, 33 ILM 1153 (1994) (GATT 1994).

53 WTO Agreement: Marrakesh Agreement Establishing the World Trade Organization, 15 April 1994, 1867 UNTS 154, 33 ILM 1144 (1994) (Marrakesh Agreement or WTO Agreement); Article II: 1 of the WTO Agreement.

54 Other so-called non-trade concerns include environment and human rights; Gokce (n 12).

55 Art III WTO Agreement.

56 http://www.wto.org (accessed 12 June 2018).

57 Provided for in GATT 1994 (n 52) arts I and II.

58 Saurombe \& Nkabinde (n 49) 430. 


\subsection{Enablers of development?}

Trade goes hand-in-hand with development, but 'is not the sole determinant for development'.59 At the same time, when trade can ensure development, this ultimately could lead to 'new goals of human happiness and well-being'. ${ }^{60}$ Arguably, it is impossible for development to flourish where there is extreme economic and social under-development. The multilateral trading system has been beneficial for developed states, but there is an acknowledgment that even with the WTO, developing countries, especially African states, have been unable to reap the supposed benefits. Some scholars who argue that this organisation is more aligned with developed country needs have put the responsibility for this state of affairs at the inner caucus of the WTO. ${ }^{61}$ In order to properly entertain this matter several pertinent issues manifested within the WTO need to be discussed:

\subsubsection{The 'single undertaking'}

Unlike the GATT, the WTO purportedly is more focused on encouraging development and to ensure the expansion of trade and involvement of the less developed world. It is commonly reasoned that WTO agreements were sold as a solitary package, the idea being that at their core these agreements are irrefutably linked. Also, the rationale for the construction of the 'single undertaking' was to ensure certainty and predictability in the trade relations between member states. Knowing the potholes that normally arise within treaty-making processes in public international law and the inconsistency with the previous GATT, the drafters were keen to avoid similar difficulties. However, Saurombe and Nkabinde argue that instead of generating the certainty, the current set-up within the WTO has 'made it impossible to reach agreement because countries are at different levels of economic development and follow different approaches in implementing their agendas'. ${ }^{62}$ Moreover, the 'single undertaking', compared to the GATT à la carte, is limiting the national policy space

59 E Gokce 'Session 2: The right to development: A tool to boost coherence between trade, development and human rights?' Panellist discussion on 15 September 2010 https://www.wto.org/english/forums_e/public_forum10_e/session02_summ _e.doc (accessed 14 June 2018).

60 A Sengupta 'Realising the right to development' (2000) 31 Development and Change 554.

61 M Khor Implications of some WTO rules on the realisation of the MDGs Third World Network August 2005, www.twn.my/title2/par/mk004.doc (accessed 21 August 2015); J Stiglitz \& A Charlton Fair trade for all: How trade can promote development (2006) 1.

62 Saurombe \& Nkabinde (n 49) 440. Alonso elaborates that '[d]evelopment problems and capacities are diverse in accordance with countries' conditions; and, consistently, any inclusive development agenda must be more complex and comprehensive than ever before'; JA Alonso 'Development cooperation to ensure that none be left behind' March 2018 Committee for Development Policy Background Paper 39 ST/ESA/2018/CDP/39, https://www.un.org/development/ desa/dpad/cdp-background-papers/ (accessed 25 March 2019). 
of states, thus especially inhibiting the growth and economic prosperity of African countries. This has resulted in such states imploring the WTO to allow for enhanced policy space and flexibilities in the multilateral trading system.

\subsubsection{Special and differential treatment}

Contrary to the WTO envisaged plan it is argued that the 'single undertaking' also further weakens the Special and Differential Treatment (SDT) provisions. ${ }^{63}$ The singular purpose of the SDT, a central feature of the past GATT (Article XVIII) and now the WTO system, is to address the needs of members that are not at a required stage of development, in order to implement measures and actively participate as such. ${ }^{64}$ These measures date back to the pre- and postUruguay Round. Ademola Oyejide explains that the SDT

constitute[s] a set of rights and privileges that apply to developing and least-developed country members and from which industrial countries are excluded. In effect, these provisions are meant to grant developing countries and least-developed countries (LDCs) more favourable access to the markets of the industrial countries and to give them substantial policy discretion with respect to their own domestic markets. ${ }^{65}$

As such, after the Uruguay Round the SDT provisions allow developing and least-developed countries 'special rights', affording them some leeway in respect of meeting their trade obligations. ${ }^{66}$ However, De Vylder comments that the SDT not necessarily is envisioned to strengthen such countries' trade and development. ${ }^{67}$ This assemblage of SDT provisions in the different agreements has been put into place to gradually reduce the dependence on such assistance, but the continuing lack of development ignites frequent questions about their actual significance. ${ }^{68} \mathrm{Ngang}^{\prime} \mathrm{s}$ argument may provide a rational explanation for the ineffectiveness of programmes such as SDT, as he contends

63 The special provisions include longer time periods for implementing agreements and commitments; measures to increase trading opportunities for developing countries; provisions requiring all WTO members to safeguard the trade interests of developing countries; support to help developing countries build the capacity to carry out WTO work, handle disputes, and implement technical standards, and provisions related to least-developed country (LDC) members, https://www. wto.org/ (accessed 25 March 2019).

64 RH Bhala 'Mercy for the Third World through GATT Article XVIII' (2002) 6 Singapore Journal of International and Comparative Law 498.

65 T Ademola Oyejide 'Special and differential treatment' in B Hoekman, A Mattoo \& P English Development, trade and the WTO: A handbook (2002) 504.

66 As above (my emphasis).

67 S de Vylder The least developed countries and world (2007) 95.

68 Bhala explicates that SDT are viewed as 'inadequate and counterproductive'; Bhala (n 64) 498. 
that global development paradigms cannot apply uniformly, especially in addressing issues relating to poverty and socio-economic and cultural development, which although perceived as global concerns, are in effect more localised in developing countries. ${ }^{69}$

Saurombe and Nkabinde put these arguments into perspective, as follows: ${ }^{70}$

Special and differential treatment operates on the basis of lumping all emerging and developing countries together into one supposedly homogenous group of developing countries' that need the same kind of treatment because they share characteristics, especially in economic development.

It is the submission that the creation of the SDT is a further acknowledgment of the fact that states are not equal. ${ }^{71} \mathrm{~A}$ perusal of African countries suggests that such countries cannot harness the benefits of the multilateral trading system, even with the aid of the SDT. Even though the SDT allows for differentiation between developed and less-developed countries, it fails to go a step further by recognising that the latter countries also differ from each other. These measures in their current form cannot be applied uniformly as states are politically, economically and socially different. Hence, the 'onesize-fits-all' approach in the form of the SDT is not suitable for addressing and actualising the development needs of these states. Heeding the call for reform to SDT provisions, the Bali Ministerial Conference in 2013 'established a mechanism' which allowed for the review and analysis of such measures. ${ }^{72}$ Despite these developments, an issue that emerges in these discussions is how SDT provisions and other measures can be used to actualise the development of African countries.

\subsubsection{Agriculture}

Another matter that is contributing to the inability to realise the development of and bringing African countries into the fold of the multilateral trading system is the continued ostensible discrepancy in agricultural trade. ${ }^{73}$

Although there are ample SDT measures in the various WTO agreements, one fundamental area where developing countries have been unable to make a direct and noticeable effect and where the continued differential approach is observed is agriculture. As such, much more flexibility and certainty is needed on issues such as domestic support and market access in agriculture, which is the

69 C Ngang 'Differentiated responsibilities under international law and the right to development paradigm for developing countries' (2017) 11 Human Rights and International Legal Discourse 287 (my emphasis).

70 Saurombe \& Nkabinde (n 49) 441.

71 Ngang (n 69) 287.

72 https://www.wto.org/ (accessed 25 March 2019).

73 Saurombe \& Nkabinde (n 49) 442. 
cornerstone of African trade and prospective development. Agricultural production in Africa is key because of the arable land available for food production and other economic and social benefits. According to the African Development Bank, agriculture in Africa is key to unlocking export growth. It estimates that more than 65 per cent of the world's arable land is located in Africa. ${ }^{74}$

Furthermore, Viljoen puts African reliance of agriculture into perspective by explaining: ${ }^{75}$

Since 2001, Africa's agricultural imports account for around 60 per cent of Africa's total trade in agricultural products. Over the last 15 years, Africa's agricultural imports increased from US $\$ 17$ billion in 2001 to US $\$ 61$ billion at the end of 2016. On average, agricultural product imports account for 13,4 per cent of the total products imported by African countries over the last 15 years, while agricultural exports account for 9,16 per cent of total African exports over the same time.

Saurombe and Nkabinde aptly point out that 'agriculture is a key area for developing countries, since most of them are becoming increasingly competitive in the agricultural and value added processed food products sectors' ${ }^{76}$ Despite its importance and the controversy surrounding trade in agriculture, the GATT from the outset, according to Ostry, 'for all practical purposes excluded agriculture' from its disciplines. ${ }^{77}$ The protectionism proffered by developed countries in the form of subsidies has always been a cause of disagreement between various countries, to the extent that it has derailed many talks and progress within the WTO.

If the AU intends to succeed with Agenda 2063 it needs to set forth a firm plan to challenge those issues relating to agriculture that impede the realisation of the right to development of African countries. In this case the AU should focus not only on the problems at the multilateral level but should also include bilateral and regional agreements on agricultural issues, as these agreements sometimes are used as a back door to complete negotiations that failed at the multilateral stage. Especially within the bilateral negotiations involving developed and less-developed countries, issues directly or indirectly linked to agriculture have been concluded that do not enable development. Reiterating Oppong's views that the aggressive liberalising of agricultural trade policies should be set aside, the WTO

74 W Johwa 'Agriculture marked as Africa's path to prosperity, and Dube Port is an example of what is achievable' Business Day 24 May 2018, https://www.business live.co.za/bd/world/africa/2018-05-24-agriculture-marked-as-africas-path-to-pros perity--and-dube-port-will-play-a-key-role/ (accessed 14 September 2018).

75 W Viljoen 'The face of African agriculture trade' 17 May 2017 https://www.tralac. org/ (accessed 14 June 2018).

76 Saurombe \& Nkabinde (n 49) 432.

77 S Ostry 'Trade, development, and the Doha Development Agenda' in D Lee \& R Wilkinson (eds) The WTO after Hong Kong: Progress in, and prospects for, the Doha Development Agenda (2007) 26. 
instead should concern itself with enabling trade rules that are 'just, fair and equitable for developing countries'.78 Importantly, agricultural and related commitments that have the potential to recognise the needs of less-developed states, the region, the community and, last but not least, the individual, should be the focus of further negotiations.

\subsubsection{Doha Development Agenda}

After the Uruguay negotiations and before Doha, developing countries had done some self-reflection which enabled them to bring to the fore their collective concerns. The advent of the Doha Development Round in 2001 for the first time underlined development as being a key focus for addressing the needs of developing countries. ${ }^{79}$ The plan by the WTO to make trade more development-focused initially showed potential.

Along with the Millennium Development Goals (MDGs) (in particular Goal 8), Doha represented a new dawn for the WTO in terms of gaining the favour of the developing and least-developed world. Broadly speaking, the objective of the Doha Development Agenda (DDA) was to 'lower trade barriers to facilitate increased global trade'. ${ }^{80}$ Essentially, Cho puts into perspective that the focus of the Doha discussions was to provide a platform for discussing the 'development issues' (in light of the events that preceded it, the 11 September terrorist attacks) and the aspirations of developing countries. $^{81}$ Consequently, it was clear that the development needs of these countries were a 'distraction' for developed nations from the political and other economic problems they encountered.

Despite the ongoing events, developing countries were eager to come to Doha and to commence discussions on their terms. Cho appropriately notes that '[d]eveloping countries viewed the Doha Development Agenda (DDA) as an avenue for reducing or eliminating old, unfair protection by developed countries that the skewed Uruguay Round deal failed to resolve. ${ }^{82}$ The expectations of these countries were presented in the Doha Ministerial Declaration, which emphasised: ${ }^{83}$

Paragraph 1: The multilateral trading system embodied in the World Trade Organization has contributed significantly to economic growth, development and employment throughout the past fifty years.

\footnotetext{
78 Oppong (n 34) 145.

79 Saurombe \& Nkabinde (n 49) 432.

80 Doha WTO Ministerial 2001: Ministerial Declaration WT/MIN(01)/DEC/1 20 November 2001, www.wto.org (accessed 25 May 2018).

81 S Cho 'The demise of development in the Doha Round negotiations' (2010) 45 Texas International Law Journal 574.

82 Cho (n 81) 575.

83 Doha WTO 2001 (n 80) (my emphasis).
} 
Paragraph 2: International trade can play a major role in the promotion of economic development and the alleviation of poverty. We recognize the need for all our peoples to benefit from the increased opportunities and welfare gains that the multilateral trading system generates. The majority of WTO members are developing countries.

Paragraph 3: We recognize the particular vulnerability of the least developed countries and the special structural difficulties they face in the global economy. We are committed to addressing the marginalization of least developed countries in international trade and to improving their effective participation in the multilateral trading system.

Unfortunately, the events that followed the Doha discussions revealed that developed and developing countries were not of the same mind in respect of the purposes of this round. According to Cho the reason was the 'philosophical divergence on the nature of the Doha Round'. ${ }^{84}$ In a sense, it appeared as though there was a Utopian sense of false hope that developed countries would make a 360 degree change in their trade practices, and that less-developed countries would become more independent and ultimate plan of SDT provisions. $^{85}$

The scepticism about Doha was not unwarranted. It did not offer a sustainable development plan for Africa's trade problems and, inevitably, once the fate of Doha was realised, such countries merely continued their reliance on the SDT. ${ }^{86}$ Arguably, their response was understandable as what was offered (including amendments to the Agreement on Trade-Related Intellectual Property Rights (TRIPS)) ${ }^{87}$ to African countries was not (at that stage) considered topical for enabling the realisation of their developmental needs. Viewed in this light, falling back to the trusted SDT was regarded as the most apt strategy.

Interestingly, the authors reason that 'African countries have seen SDT, including Aid for Trade (AfT) as their sole positive interest in the agenda' ${ }^{88}$ Moreover, the earlier objectives of the DDA called for 'policy space for developing countries, notably through effective SDT provisions in favour of developing countries'. ${ }^{89}$ Even with the increased focus on the SDT, a more flexible approach that included civil, political and socio-economic matters such as capacity building, technical assistance for addressing, for example, non-tariff barriers, health and education, needs to be considered. In fact, a proper

84 Cho (n 81) 575.

85 Cho 575-576.

86 MF Jensen \& P Gibbon 'Africa and the WTO Doha Round: An overview' (2007) 25 Development Policy Review 6.

87 Jensen \& Gibbon (n 86) 6.

88 As above.

89 R Davies 'Outcome of the 11th WTO Ministerial Conference (MC11) held in Buenos Aires, Argentina, 10-13 December 2017' Presentation to Parliamentary Portfolio Committee on Trade and Industry 6 March 2018, https://www.thedti. gov.za/parliament/2018/WTO_MC11_outcomes.pdf (accessed 14 September 2018). 
development-centred approach requires a 'radical restructuring of existing trade and world economic systems', ${ }^{90}$ and is needed to give to give (especially) African countries any hope of realising their right to development.

Even in its description Doha expressed mere aspirations, with no clear and realistic targets that took into account the political, economic and social diversity among its intended beneficiaries. Jenson and Gibbon argue that Doha's overall objective was merely to appease developing countries, with no actual guarantee for creating binding commitments. ${ }^{91}$ As mentioned before, by not defining or setting rationally-linked objectives and targets as to how development should be achieved from the outset, Doha had no basis from which to operate. It consisted of mere promises made, particularly by developed countries, to reduce the burden and poverty levels in the poorer trading nations of the world.

Any plan to realise development should take into account the political and socio-economic challenges which largely affect African countries and their development prospects. Thus, even if Doha had a clear modus operandi, it most likely would not have made an impact, as Saurombe and Nkabinde argue that

[e]ven among developing countries themselves, it remains to be determined how development principles can be applied effectively in the WTO, in line with countries' diverse definitions of development and in a manner that would best satisfy all members' expectation. ${ }^{92}$

Similar to SDT measures, the WTO and its member states saw Doha as an expedient solution to a complicated situation, which needed a comprehensive plan of action to address African countries' elongated history of political, economic and social problems, which are among the many factors that triggered the lack of development. This was contextually put into place by UNCTAD, which explicated that Africa, having shown inspiring growth, as recognised by the institution, unfortunately continues to 'grapple with the challenges of poverty, unemployment, inequality, commodity dependence and environmental degradation'. ${ }^{93}$ Furthermore, during the previous rounds of negotiations it was palpable that certain issues were 'a no-go', and that by 'forcing' discussions on these matters it would most definitely lead to another walk-out. To avoid these pitfalls Doha Agenda protagonists should have been strategic by dissecting the problems one by one, rather than adding to the overflowing basket of trade issues.

As a response to some of the concerned sentiments on the inclusion of African countries in the previous WTO discussions, Africa

90 Ozoemena \& Hansungule (n 28) 228.

91 Jensen \& Gibbon ( $\mathrm{n} 86) 6$.

92 Saurombe \& Nkabinde (n 49) 433-434.

93 http://unctad.org/en/Pages/ALDC/Africa/Economic-Development-of-Africa.aspx (accessed 12 June 2018). 
for the first time hosted a Ministerial Conference. ${ }^{94}$ Nairobi, Kenya, provided the backdrop to a much anticipated round which, as stated by the WTO, 'delivered commitments that would benefit in particular the organization's poorest members' ${ }^{95}$ Notably, the conference involved landmark discussions on agriculture and development, along with issues relating to cotton and other issues of particular relevance to least-developed African countries. The offering of a special safeguard mechanism for developing countries and preferential treatment for least-developed countries made it apparent that some officials had not entirely pulled the plug from the Doha discussions. At least then, the eagerness to write an obituary for the WTO was put aside, as WTO officials and other relevant stakeholders focused on salvaging some aspects of the DDA.

However, this optimism was in ruins when a general statement that 'still no agreement could be reached on the future of the DDA'96 emerged from the discussion. It was anticipated that the Eleventh Ministerial Conference in Buenos Aires ${ }^{97}$ would revive the discussion on the role of the DDA. Despite the slight hope that emerged at Nairobi, ministerial decisions at the Buenos Aires Conference could be reached only on a limited number of issues, such as Fisheries Subsidies; the Work Programme on Electronic Commerce; TRIPS nonviolation and situation complaints; and the Work Programme on Small Economies.

Disappointingly, at this Conference, also, progress was stagnant as members once again failed to reach agreement on important matters which involved programmes on development and agriculture. ${ }^{98}$ Instead, developed countries proved to be the main driving force behind calls for members to observe the 'same set of rules, on the same level of standard', with reportedly 'very little or any differentiation' among countries. 99 This argument illustrates the prevailing misconception that existing programmes that permit differential treatment have brought about significant changes to the socio-economic systems of such countries.

Lastly, if the Doha aspirations finally succumb the WTO will be faced with further questions about its commitment to focus on development and the needs of less-developed countries. Noting the concerns about the single undertaking, the SDT, agriculture and the

94 Held 15-19 December 2015, https://www.wto.org/english/thewto_e/minist_e/ mc10_e/ nairobipackage_e.htm (accessed 12 June 2018).

95 http://wwww.wto.org (accessed 25 May 2018).

96 R Davies 'Outcome of the 11th WTO Ministerial Conference (MC11) held in Buenos Aires, Argentina from 10 to 13 December 2017' Presentation to Parliamentary Portfolio Committee on Trade and Industry 6 March 2018, https:// www.thedti.gov.za/parliament/2018/WTO_MC11_outcomes.pdf (accessed 14 September 2018).

97 Held 10-13 December 2017.

98 Davies (n 89).

99 As above. 
DDA, the WTO needs to undertake an in-depth assessment of the effectiveness of its array of current policies, programmes and practices, to determine whether in fact they are enablers of development. Notably, African countries need to revive their approach to the multilateral, regional and bilateral framework on trade and development and reassess those mechanisms on which they depend.

\section{4 'Tools' or 'mechanisms' to enable the right to development?}

Noting the dismay in the multilateral trade system, there are some positive prospects in respect of the role of trade as an essential tool to revive and ultimately realise the right to development. To a great extent the prevailing sentiment is that the focus of the trade system should be to improve the socio-economic well-being of states and their people. For this reason, trade is an essential tool for internal African relations, and with partnerships external to the continent and vice versa. ${ }^{100} \mathrm{Ngang}$ argues that 'Africa's development future is only attainable through collective self-reliant consciousness: The continent's agenda for development must not be thwarted by external influences or shaped by imported paradigms. ${ }^{101}$

These sentiments are understandable as incompatible trade policies developed for African countries have not always been logical or suitable for the challenges faced. Knowing that inequity exists in multilateral trade, the proliferation of regional trade agreements (noting the newly-formed Tripartite Free Trade Area (TFTA) between the SADC, East African Community (EAC) and Common Market for Eastern and Southern Africa (COMESA) can be linked to a paradigm shift in the policies of a number of especially African (and other Third World) countries toward a more internal liberal trade approach. The UN General Assembly Agenda for Development also emphasised that '[n]otwithstanding the importance of a favourable international economic environment, ultimately each country bears primary responsibility for its own economic and social policies for development'. ${ }^{102}$

Even though the above statement reflects the internal responsibility of states, the sentiments echo the importance of 'sound and stable policies' as being a key part to driving Africa's overall trade and development approach. To this end, there are several trade-related external and internal tools or mechanisms that over the years have been utilised interchangeably by developing and least-developed countries.

100 Ngang (n 9) 108; Ozoemena \& Hansungule (n 28) 228; Cheru (n 23) 1279.

101 Ngang (n 9) 108.

102 United Nations General Assembly Resolution 'Agenda for Development' 51st session Agenda item 96(b) A/RES/51/240 15 October 1997 (my emphasis). 
At the beginning of this article reference was made to African countries' reliance on official development assistance. Essentially, official development assistance is defined as 'government aid that promotes and specifically targets the economic development and welfare of developing countries'. ${ }^{103}$ There have been ample changes in the development aid system which have been linked with global agendas such as the MDGs and Sustainable Development Goals (SDGs) and these changes also resulted in the review of the official development assistance and other practices to improve the effectiveness of aid. ${ }^{104}$ As the dynamics in international landscape change, according to Alonso even more changes are on the cards. ${ }^{105}$ Least-developed countries (prevalent in Africa) face daunting challenges ranging from pervasive poverty and dependence on development assistance.

Programmes such as the Enhanced Integrated Framework (EIF multi-donor programme $)^{106}$ and the AfT initiative underpin the objective and purpose of the RTD Declaration. These programmes enable least-developed countries to 'harness trade for poverty reduction, inclusive growth and sustainable development'. ${ }^{107}$ Despite the overall relevance of official development assistance and other development aid systems, African countries must be cautious of not becoming too reliant and being subjected to onerous terms and conditions. Indeed, so-called global partnerships focused on coordinating financial and technical mechanisms to address the constraints and build trade capacity of such countries in order to eliminate social challenge are needed, but countries must be allowed a degree of flexibility to enable policies that are aligned with their national, regional and international development goals. These forms of development systems can play a role in addressing the marginalisation and inequality in trade relations between states and ultimately realising the right to development.

Seemingly, one area in particular has been the focus of attention, namely, agriculture. Here Enhanced Integrated Framework programmes have been incorporated into the relevant country's existing programmes to embrace the country's unique characteristics and thus develop a work plan that includes 'human and institutional capacity, government commitment and managing resources'. ${ }^{108}$ As such, with the appropriate combination of policies and practices and

103 OECD 'What is ODA?' April 2018, https://www.oecd.org/dac/financing-sustain able-development/development-finance-standards/What-is-ODA.pdf (accessed 25 March 2019).

104 Alonso (n 62) 2.

105 As above.

106 The EIF consists of 51 countries, 24 donors and eight partner agencies, https:// www.enhancedif.org/ (accessed 31 May 2018).

107 http://www.wto.org (accessed 31 May 2018).

108 R Adhikari \& J Edwin 'How is the Enhanced Integrated Framework supporting LDCs to unleash their trade potential?' 8 November 2017, http://www.ictsd.org (accessed 31 May 2018). 
considering other factors, the salient golden thread that runs between development and international trade is visible. The Enhanced Integrated Framework provides a framework to ensure the efficient and optimal use of trade to realise development, ${ }^{109}$ but should not be seen as the lone device, as African countries need to focus on establishing internal measures to address their development needs.

Agenda 2063 is a step towards addressing Africa's challenges. As explained by Jensen and Gibbon, 'many of the problems or impediments to African trade, such as poor infrastructure and low and skewed foreign investment, political violence and instability' are not within the ambit of the WTO and, therefore, have to be addressed by internal policies and programmes. ${ }^{110}$ Thus far, these internal matters have not been successfully resolved through national processes. Thus, Agenda 2063 drafters were cognisant of these regions' internal conflicts that can be resolved only through the collective effort of African countries. The abundant civil, political and economic problems facing African countries have led to the overwhelming support for the $\mathrm{AU}$ to devise a fundamental list of aspirations for Africa. These included an integrated continent, politically united and based on the 'ideals of pan-Africanism and the vision of Africa's renaissance; peace and security; having a strong cultural identity, common heritage, values and ethics; and where development is people-driven, unleashing the potential of its women and youth'. ${ }^{111}$ To ensure this plan, the $\mathrm{AU}$ needs to revise and strengthen its 'peer and internal reviews' which include, for example, the African Peer Review Mechanism (APRM), to ensure that its members address these barriers to development.

Agenda 2063 still has a long way to go, but it is a rational approach toward reviving the right to development through addressing the internal challenges faced by African countries, to enhance their abilities to deal with external challenges. Thus, unlike the MDGs and the Doha Development Agenda, Agenda 2063 acknowledges the substantial nature of the problems of African countries, as its longterm vision is to provide 'a strategic framework for the socio-economic transformation of the continent'.112 Global partnerships undeniably are essential, but African countries need to pursue internal means to realise their development and progress on the multilateral trade stage. More so, the responsibility is bestowed on states to facilitate poverty reduction policies or programmes and nurture relations, and cooperation in the multilateral trade and human rights framework.

The surge in the formation of regional trade agreements is viewed largely as a means to ensure that Africa ultimately can fully participate and become a fully-functioning partner in the multilateral trade

109 As above.

110 Jensen \& Gibbon (n 86) 5.

111 https://au.int/en/agenda2063 (accessed 25 May 2018).

112 African Union Commission (n 6). 
system. ${ }^{113}$ Now might be the most appropriate time to use regional trade agreements and customs unions (ambitiously through the much-anticipated TFTA), in light of the long-term goal to establish Africa as a 'strong, united, resilient and influential global player and partner', 114 to realise African citizenry's right to development. Concerns about the viability of the WTO and the institution's lacklustre approach in effectively addressing the needs of developing and least-developed countries have contributed to this proliferation. However, even as the regional trade agreements proliferate, a comprehensive plan is required as these developments have also presented unforeseen difficulties, ranging from socio-economic and political and overlapping memberships, especially for the SADC, COMESA and EAC in the newly-formed TFTA trading regime. ${ }^{115}$ As such, these tools and other development policies and collective partnerships at the multilateral, regional and national levels are crucial for ensuring equitable economic relations and cooperation, and enabling the realisation of the right to development.

\section{Way forward}

From the discussion, the normative and legal framework recognises the differences and the link between the right to development, other human rights and fundamental freedoms and trade. Without a doubt, the right to development encompasses a comprehensive framework and sets out particular approaches that can be harnessed at the international, regional and national levels, for states to assert their full sovereignty over their natural resources and improve the welfare of those within their borders. With the right to development being universal, African countries, due to their high unemployment rates, dire poverty and bleak economic development, and more so now with the various plans set out in Agenda 2063, should focus on reviving development through the multilateral trade system.

There is ample room for the inclusion of the right to development in the multilateral trade framework, as trade is a valuable tool for the realisation of the development of African countries. Indeed, trade practices and policies should be intersected and symbiotic with the right to development. Otherwise, what purpose do they serve?

113 UNDP Africa Policy Brief Strengthening Strategic Alignment for Africa's Development: Lessons from the UN 2030 Agenda for Sustainable Development, the African Union's Agenda 2063, and the AfDB's High Fives, http://www. africa.undp.org/content/dam/rba/docs/Working\%20Papers/UNDP\%20Africa\%20 Policy\%20Brief\%20on\%20Strengthening\%20Strategic\%20Alignment\%20for\%20 Africa\%20(24\%20January\%202017)\%20-\%20ENGLISH.pdf (accessed 10 March 2019).

114 ttps://au.int/en/aspirations (accessed 25 May 2018).

115 J Mapuva \& L Muyengwa-Mapuva 'The SADC regional bloc: What challenges and prospects for regional integration?' (2014) 18 Law, Democracy and Development 25. 
Furthermore, the connection between trade and development is mirrored in the Preamble to the WTO, by reference to aims such as 'raising standards of living', 'ensuring full employment' and 'sustainable development'. ${ }^{1 \top 6}$ 'Other challenges as a result of structural and operational impediments in multilateral trade would also need to be revised, if the WTO intends to regain its standing and ensure the survival of the multilateral trade system. In this respect, blame must also be levelled at the so-called 'one-size-fits-all' policies, which fail to consider the position of developing and least-developed countries.

Despite positive effects of the SDT and the relevant development assistance mechanisms, these cannot be regarded as the sole means to address the development needs of African countries. Allowing for the continuation of reliance on programmes or policies that are not reasonably paralleled with the socio-economic and political aspirations of African countries may result in the early demise of Agenda 2063. In the short term, African countries should address the underlying concerns with these existing programmes and policies through regional and bilateral discussions.

The plans set forth in Agenda 2063 will not provide an immediate answer to the lingering question of how the realisation of the right to development can be ensured by multilateral trade practices and policies. For Africa, which has witnessed the formation of a number of regional communities that not only serve an economic purpose, but also a political and social purpose, the plan is to shift the focus to regionalism. By incorporating this inward focus, African countries could ultimately become more influential and fully-fledged global players on the various international stages. Nonetheless, there is room for optimism for the revival of the right to development within the multilateral trade framework. 